\title{
ANALYTICAL APPROACHES IN UNVEILING THE COMPATIBILITY OF COLLAGENASE WITH ADDITIVES IN VIEW OF ITS COLLOIDAL DELIVERY
}

\author{
LANDGE ANIL VIJAY, KRISHNAMOORTHY KANNAN* \\ Department of Pharmacy, Annamalai University, Annamalainagar-608002. Tamilnadu, India
}

\begin{abstract}
The core objective of present work was to investigate the chemical interactions of selected additives with therapeutic enzyme Collagenase (COLG) and determination of its compatibility for futuristic colloidal formulation. Initially, solubility of COLG with additives was determined and emulsification efficiency of surfactants was examined. FTIR spectra of COLG with its binary blends were compared. Non-denaturing SDS-PAGE and Circular Dichroism (CD) used to investigate primary and secondary structure of enzyme in binary mixture. Finally, the control and accelerated studies was performed by spectroscopy.
\end{abstract}

Keywords: Collagenase, FTIR-ATR, SDS-PAGE, Circular Dichroism.

\section{INTRODUCTION}

In case of biopharmaceuticals formulation and its quality, retaining the ideal native form of native therapeutic protein is a crucial fact. From the stage of its isolation in pool of complex biological entity including the mixture of denatured, degraded and unfolded confirmations of the same or other proteins till its purification and storage as biopharmaceuticals, a major hurdle is to perpetuate the integrity of the native folding of protein due to addition of varieties of additives [1].

It is sensible and imperative to determine the compatibility and stability of such therapeutic macromolecules in presence of additives employed during formulation processes by adopting various analytical methods. Many indirect and direct analytical techniques are being adopted in ascertaining compatibility of enzymes with additives to investigate its long-term activity and stability [2].

Clostridial collagenases (COLG) are the bacterial proteases typically known as "metalloproteinases" necessitate the digestion of the extracellular matrices of animal cells, due to their native collagen breakdown potential. These are remarkably found in treating varieties of fibro-proliferative disorders [3]. The nature of COLG enzyme and its restricted potential in penetrating stratum corneum limits itself in delivering into deeper skin strata which result in forfeiting its efficacy at the localized site of dermal/epidermal border [4].

Colloidal systems have secured significant attention over the years due to their thermodynamic stability, optical clarity, and simplicity of preparation. Colloidal solutions viz. Water-in-oil (w/o) and oil-in-water $(\mathrm{o} / \mathrm{w})$ microemulsions reported as carriers of water-soluble/insoluble proteins and enzymes [5].

The study involves preformulation aspects and compatibility determination of COLG with different additives in the fabrication of colloids in concern with its storage, long-term stability and activity by employing specific analytical techniques.

\section{EXPERIMENTAL}

Collagenase (COLG) enzyme was previously isolated from Clostridium novyi - NT, a novel and non-virulent clostridial strain [6]. The enzyme was further purified, lyophilized and protein concentration was determined. Ringer's solution (Ringer's Injection USP) was procured from Parenteral Enzymes (I) Ltd, Indore; Madhya Pradesh (India). All other chemicals including standard protein molecular weight marker $(20-200 \mathrm{kD})$ are procured from Sisco Research Laboratories Pvt. Ltd., Mumbai (India). All chemicals and reagents used were AnalaR grade.

\section{Solubility studies}

The solubility of COLG was assessed visually by adding an excess amount of the enzyme in $2 \mathrm{ml}$ in various oils and surfactants. Further, the enzyme was added with increasingly larger amounts of solvents using vortex mixer (Fisher Scientific, UK) for one minute. The solutions were further sonicated to reduce air bubbles and examined visually for any signs of crystallization or precipitation if any at $20^{\text {th }}$ minutes, $24 \mathrm{~h}, 48 \mathrm{~h}$, and $72 \mathrm{~h}$. Solubility $(\mathrm{mg} / \mathrm{ml})$ was determined by dividing of the enzyme weight $(\mathrm{mg})$ with weight of solvent $(\mathrm{ml})$ required to obtain a clear solution after $72 \mathrm{~h}[7,8]$.

\section{Preliminary screening of different surfactants for ability of emulsification}

For emulsification of selected oils viz. isopropyl myristate (IPM), oleic acid (OA) and ethyl oleate (EO) different surfactants were screened. Briefly, $600 \mathrm{mg}$ of the surfactants (including Tween 20, Tween 80 and Span 80) was added to $600 \mathrm{mg}$ of oleic acid. The mixtures were further homogenized by heating at $50^{\circ} \mathrm{C}$ for $15 \mathrm{~min}$. About $50 \mathrm{mg}$ of each mixture was weighed and diluted to $50 \mathrm{ml}$ with Ringer's solution in a stoppered conical flask to produce a homogenous emulsion. The turbidity of the resulted emulsions was visually inspected. The resulted emulsions in the flask were left to stand for $3 \mathrm{~h}$ and then the \% transmittance was determined on UV-spectrophotometer (JascoV-530) at 650 $\mathrm{nm}$ using Ringer's solution as a blank. The experiment was carried out in triplicate [9].

\section{Preliminary screening of cosurfactants}

The chosen oil phases and surfactants were employed in screening of the various cosurfactants - propylene glycol (PG) and glycerol (GLYC) for their emulsification efficiency. Mixtures of $200 \mathrm{mg}$ of cosurfactant, $400 \mathrm{mg}$ surfactant and $600 \mathrm{mg}$ oil were prepared. These mixtures were heated further at about $50^{\circ} \mathrm{C}$ for $15 \mathrm{~min}$ and homogenised. Each mixture about $50 \mathrm{mg}$ was weighed and diluted further to $50 \mathrm{ml}$ with Ringer's solution to get the fine emulsion. The relative turbidity of the resulted emulsions was visually inspected. Then, the emulsions were left undisturbed for $2 \mathrm{~h}$ and their \% transmittance was determined by UVspectrophotometer (JascoV-530) at $650 \mathrm{~nm}$ using Ringer's solution as a blank. The turbidity of the resulted emulsions ensures the relative efficiency of the cosurfactants in improving the colloidal formation ability of surfactants [9].

\section{Compatibility testing of COLG with additives}

The widely used sophisticated techniques to study compatibility interactions are Differential scanning calorimetry (DSC), Fourier-transform infrared spectroscopy (FTIR) and determination of isothermal stress studies by means quantitative spectroscopy or HPLC methods. FTIR spectra assure the rapid interpretation of possible incompatibilities with quantification of wave numbers of the specific functional group at particular region [10]. Non-denaturing type Sodium dodecyl sulfate - polyacrylamide gel electrophoresis (SDS-PAGE) or native PAGE is popularly employed in determining the aggregation and denaturation of protein in a binary mixture. It also focuses on the undisturbed oligomeric behaviour of protein since in case of SDS-PAGE there would be the generation of oligomeric subunit forms of proteins resulted due to the presence of denaturants leading to confusion during compatibility interaction [11]. The IST includes storage of enzyme-additive blend at elevated temperature to accelerate enzyme aging and interaction with additives. The average duration of study could be around 3-4 weeks [12]. 


\section{Preparation of physical mixtures/binary blends}

Physical mixtures of enzyme and different additives of interest were prepared as binary blends at a concentration of $2 \mathrm{mg} / \mathrm{ml}$ in Eppendorf tubes $(n=3)$. The additives used for this study were IPM, oleic acid, Tween 80, PG and GLYC. The tubes were mixed on a vortex mixer for $2 \mathrm{~min}$. Three sets of Eppendorf tubes were prepared as per the protocol outlined above. One set of tubes were analyzed as soon as prepared. The second sets of samples were assigned as control samples and stored at $5 \pm 3^{\circ} \mathrm{C}[13,14]$. These samples were evaluated further by FTIR, non-denaturing SDS-PAGE while third sets of samples were stored for isothermal stress studies (IST) at $25^{\circ} \mathrm{C} \pm 2{ }^{\circ} \mathrm{C} / 60 \pm 5 \% \mathrm{RH}$ in dark stability chamber as per ICH guidelines. After 4 weeks these samples were withdrawn and analyzed quantitatively by using UV-spectrophotometer [15-17].

\section{Visual observations}

The binary blends of enzyme and additives subjected for compatibility studies were initially inspected for any visual changes including colour and gas formation [13]. An Absence of any kind of change in each binary blend propounded as possible compatibility of COLG with the selected additives.

\section{FTIR spectrometric analysis}

The infrared spectra of the enzymes and physical mixtures (prepared as described previously) were recorded using a Diamond ATR (attenuated total reflection) accessory (MKII Golden Gate ${ }^{\mathrm{TM}}$, SpecacInc, USA) using a Bio-Rad FTS 3000 MX spectrophotometer (Bio-Rad, USA). All spectra were calculated from 28 scans (each containing 2038 points), in the wavelength number range of 700-4000 cm-1. Data were acquired with the Resolution Pro software v.5.2.0 (Agilent Technologies, USA) [18].

\section{Non-denaturing SDS-PAGE and densitometry}

To evaluate the uniformity of protein band volumes (area) and possible fragmentation or covalent aggregation of the COLG products, SDS-PAGE was carried out under non-reducing conditions. Identification of COLG was carried out on $12 \%$ polyacrylamide gels. Proteins bands were made visualized by Coomassie Brilliant Blue staining to determine the relative molecular weight of COLG. Reference protein ladder was employed for molecular weight comparison. Gels were further destained by the methanol-acetic acid mixture. The destained gels were imaged and analyzed using GelQuant software (BiochemLab Solution). The band volumes (pixel intensity) of the peaks corresponding to the COLG standards concentrations were recorded and the amount was calculated from the regression equation obtained from the calibration plot $[14,19-20]$

\section{Circular Dichroism (CD) Spectroscopy}

COLG solution $(1 \mathrm{mg} / \mathrm{mL})$ was prepared in sterile Ringer's Solution. The binary solution mixture of the permeation enhancers' viz. OA with PG (1:1), OA with GLYC (1:1) and OA with Tween 80 (1:1) were prepared in sterile Ringer's solution and sonicated for $5 \mathrm{~min}$. Aliquots of $0.5-\mathrm{mL}$ COLG solutions $(1.0$ $\mathrm{mg} / \mathrm{ml}$ ) were added and mixed with a $0.5-\mathrm{mL}$ of previously prepared permeation enhancers by vortexing.

The above solutions were scanned from 190 to $250 \mathrm{~nm}$ on the Circular dichroism spectrometer (Jasco J-715 spectropolarimeter, Tokyo, Japan) at a scanning speed of $50 \mathrm{~nm} / \mathrm{min}$ at $25^{\circ} \mathrm{C}$. A $10-\mathrm{mm}$ pathlength quartz cuvette was employed to obtain optimum resolution. The spectra were recorded and the molecular ellipticities measured. The spectra comprise an average of three scans $[21,22]$

\section{Content analysis by UV spectrophotometer for isothermal stress studies}

Binary blends of the enzyme with oil, surfactants and cosurfactants meant for IST studies were withdrawn after 4 weeks. These blends of the enzyme with oil, surfactants and cosurfactants were diluted separately in $0.05 \mathrm{M}$ TES buffer containing $0.36 \mathrm{mM}$ of calcium chloride and $0.5 \%$ sodium deoxycholate $\mathrm{pH} 7.5$ to get the dilution of $1 / 10$. The mixtures were incubated at $37^{\circ} \mathrm{C}$ for $1 \mathrm{~h}$ and then centrifuged at about $3000 \mathrm{rpm}$ for $3 \mathrm{~min}$ to separate the oil and surfactant phase.

$25 \mathrm{mg}$ of bovine collagen was weighed into each four test tubes. Two tubes used to serve as blanks which were without enzyme. $5.0 \mathrm{ml}$ of $0.05 \mathrm{M}$ TES buffer containing $0.36 \mathrm{mM}$ of calcium chloride, $\mathrm{pH} 7.5$ (excluding deoxycholate) was mixed to these tubes and same incubated at $37^{\circ} \mathrm{C}$ for 15 minutes. The reaction was initialized by the mixing of $0.1 \mathrm{ml}$ of diluted enzyme solution in appropriate tubes. After $5 \mathrm{hr}$, COLG reaction was stopped and followed with the withdrawal of $0.2 \mathrm{ml}$ of solution (leaving the collagen behind) and transferred to test tubes previously prepared with $1.0 \mathrm{ml}$ of Ninhydrin-citric acid mixture. A blank (collagen incubated with $0.1 \mathrm{ml}$ TES buffer instead of enzyme) was included. Tubes were heated for 15-20 minutes in a boiling water bath. After cooling, each tube was diluted with $5 \mathrm{ml}$ of $50 \%$ n-propanol, allowed to attain room temperature for 15 minutes and read absorbance at $600 \mathrm{~nm}$. From L-leucine standard curve micromole, amino acid equivalent to liberated leucine represents the units of reacted collagenase $[23,24]$.

\section{RESULTS AND DISCUSSION}

Determination of solubility of COLG

Various oils, surfactants, cosurfactants including buffer viz. Ringer's solution were screened for solubility of COLG for ME development. The solubility results are indicated in Table 1 . The data shows that solubility was highest in sterile Ringer's solution. It was followed with PG and GLYC (water-miscible solvents) and in surfactant Tween 80. Among oils, solubility was found higher in oleic acid (Figure. 1).

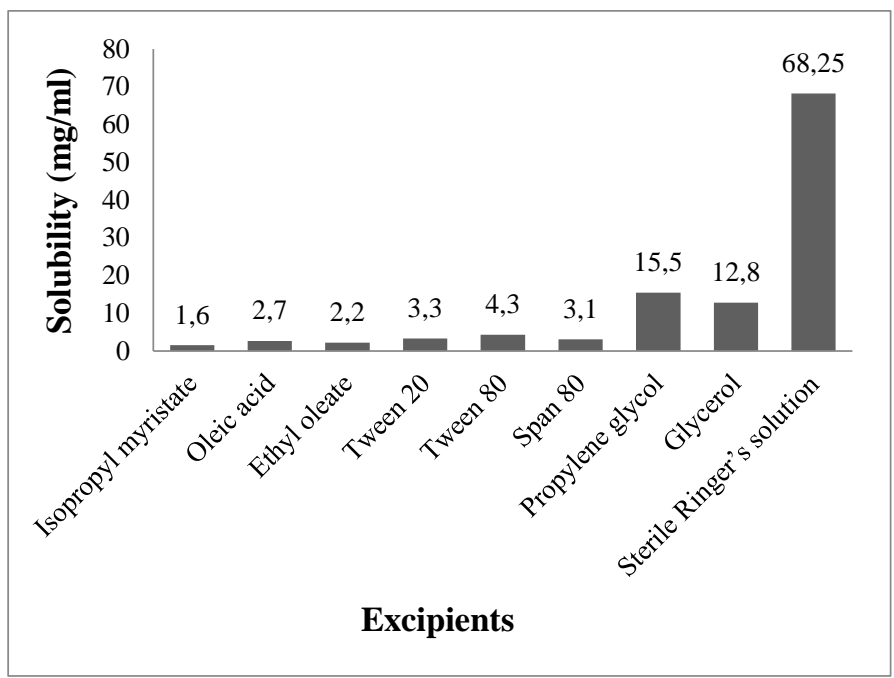

Figure 1. Phase solubility of COLG in various oils, surfactant and cosurfactants

Oleic acid had a strong permeation enhancing the effect and could increase the diffusion coefficient in the skin since it could increase the fluidity of the lipid portion of the stratum corneum and partially dissolving them. Moreover, oleic acid is also known for its antiproliferative nature which is beneficial as a counterpart of COLG enzyme characters while selection of surfactants and cosurfactants, was presided on their efficiency of emulsification [9].

Table 1. Solubility of COLG in different additives.

\begin{tabular}{|c|c|}
\hline Ingredient & Solubility $(\mathbf{m g} / \mathbf{m l})$ \\
\hline IPM & 1.6 \\
\hline Oleic acid & 2.7 \\
\hline Ethyl oleate & 2.2 \\
\hline Tween 20 & 3.3 \\
\hline Tween 80 & 4.3 \\
\hline Span 80 & 3.1 \\
\hline PG & 15.5 \\
\hline GLYC & 12.8 \\
\hline Sterile Ringer's solution & 38.2 \\
\hline
\end{tabular}




\section{Preliminary screening of different surfactants for ability of emulsification}

The dispersion with their $\%$ transmittance values are detailed in Table 2. This study clearly specifies that Tween 80 had good ability to get emulsify with oleic acid followed by Tween 20 and Span 80 . The surfactant selection is a very crucial fact in the development of colloidal formulations, and its effectiveness is governed by the HLB value which highly attributes in its stability point of view. Emulsification is also affected by the surfactant structure and chain length [25, 26]. Tween 80 was regarded as the best emulsifier for oleic acid (oil) as double bonding in its lipophilic chain contributes for enhanced oil uptake [27].

Table 2. Emulsification efficiency of different surfactants.

\begin{tabular}{|c|c|c|}
\hline Surfactant & HLB & \% Transmittance \\
\hline Tween 80 & 15.0 & $92.93 \pm 0.23$ \\
\hline Tween 20 & 16.7 & $90.51 \pm 0.84$ \\
\hline Span 80 & 4.3 & $86.77 \pm 0.55$ \\
\hline
\end{tabular}

(Data represent mean value $\pm \mathrm{SD},(\mathrm{n}=3)$.

\section{Preliminary screening of cosurfactants}

The $\%$ transmittance was used to evaluate of the efficacy of surfactant/cosurfactant combinations and thus emulsification potential of the cosurfactants. The efficiency of the emulsification due to surfactant/cosurfactant combinations are illustrated in Table 3. It is well known fact that cosurfactants are responsible in reducing the interfacial tension and thus enhances the fluidity of micellar interfacial film. This distinguishes the ability of various cosurfactants in variation of the emulsification phenomenon by the selected surfactant. Similarly, the \% transmittance values showed no significant difference between GLYC and PG as surfactant/cosurfactant combination.

The solubilization efficiency towards COLG was also taken into consideration here. The solubility of COLG was observed highest in PG in comparison with other investigated cosurfactants. Hence, PG can be chosen as a cosurfactant of choice due to its ability to enhance the emulsification with Tween 80 beyond its cosolvent nature.
Table 3. Emulsification efficiency of different co-surfactants with selected surfactants. Data represent mean value $\pm S D,(n=3)$.

\begin{tabular}{|c|c|c|c|}
\hline \multirow{2}{*}{ Cosurfactant } & \multicolumn{3}{|c|}{ \% Trasmittance (at 650 nm) } \\
\cline { 2 - 4 } & Tween 80 & Tween 20 & Span 80 \\
\hline \multirow{2}{*}{ GLYC } & $88.13 \pm 0.43$ & $86.10 \pm 0.29$ & $82.30 \pm 0.42$ \\
\hline PG & $88.46 \pm 0.51$ & $87.75 \pm 0.51$ & $81.53 \pm 0.64$ \\
\hline
\end{tabular}

\section{Visual observations}

No notable change was determined in the binary blends upon visual observation. There was no any visible colour change or gas/bubbles formation was seen in the binary blends. Other evaluations like sedimentation and cake formation also was not seen. The absence of any significant changes suggested possible compatibility of COLG enzyme with the selected additives.

\section{FTIR spectrometric analysis}

Infrared spectroscopic studies are crucial and beneficial in determination of the purity of chemical compounds. The binary blends, individual enzyme and additives were scanned in the region $4000-600 \mathrm{~cm}^{-1}$ with a resolution of $4 \mathrm{~cm}^{-1}$.

The $\%$ transmittance was plotted on the $y$-axis and wave number on the $\mathrm{x}$-axis. The enzyme represents the characteristic peaks of typical protein with primary $\left(1635 \mathrm{~cm}^{-1}\right)$, secondary $\left(1357 \mathrm{~cm}^{-1}\right)$ and tertiary amide groups $\left(1246 \mathrm{~cm}^{-1}\right)$ due to $\mathrm{CO}$ stretching, $-\mathrm{NH}$ bending and $-\mathrm{CN}$ stretching respectively (Figure. 2a).

COLG shows characteristic peaks at $3265 \mathrm{~cm}^{-1}$ (-NH stretching in resonance), $2919 \mathrm{~cm}^{-1}$ (-CH vibrations). Tryptophan and serine presence can be seen at 1076 $\mathrm{cm}^{-1}$ due to $-\mathrm{CC}$, $-\mathrm{CH}$, - $\mathrm{CO}$ stretch. Amide IV and V are confirmed at 757 and $700 \mathrm{~cm}^{-1}$ due to $-\mathrm{OCN}$ bonding and out of the plane $-\mathrm{NH}$ bonding. The obtained spectrum was observed in well agreement with the reported spectrum of COLG [28].

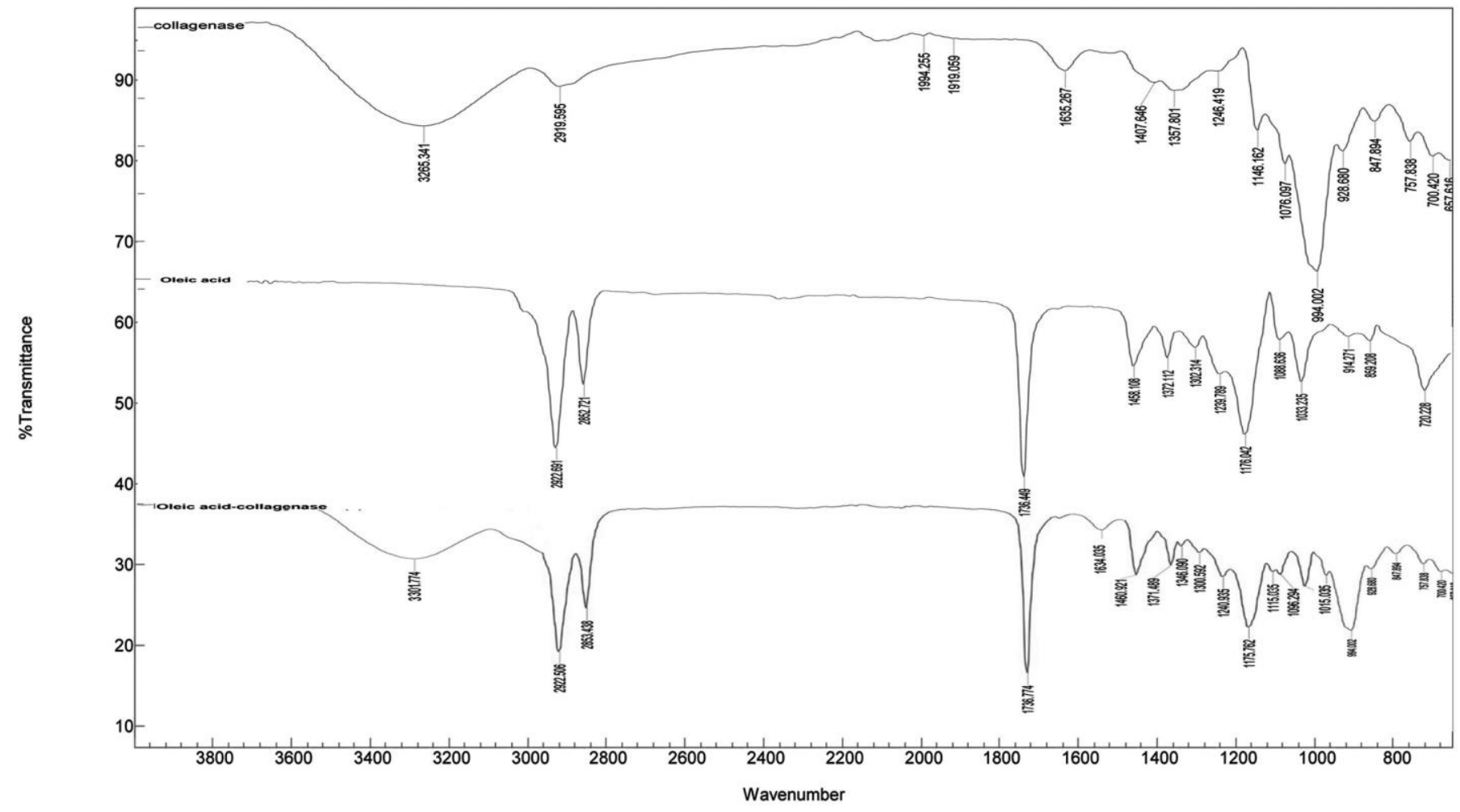

Figure 2(a). Infrared spectra of COLG, Oleic acid and COLG-Oleic acid mixture. 


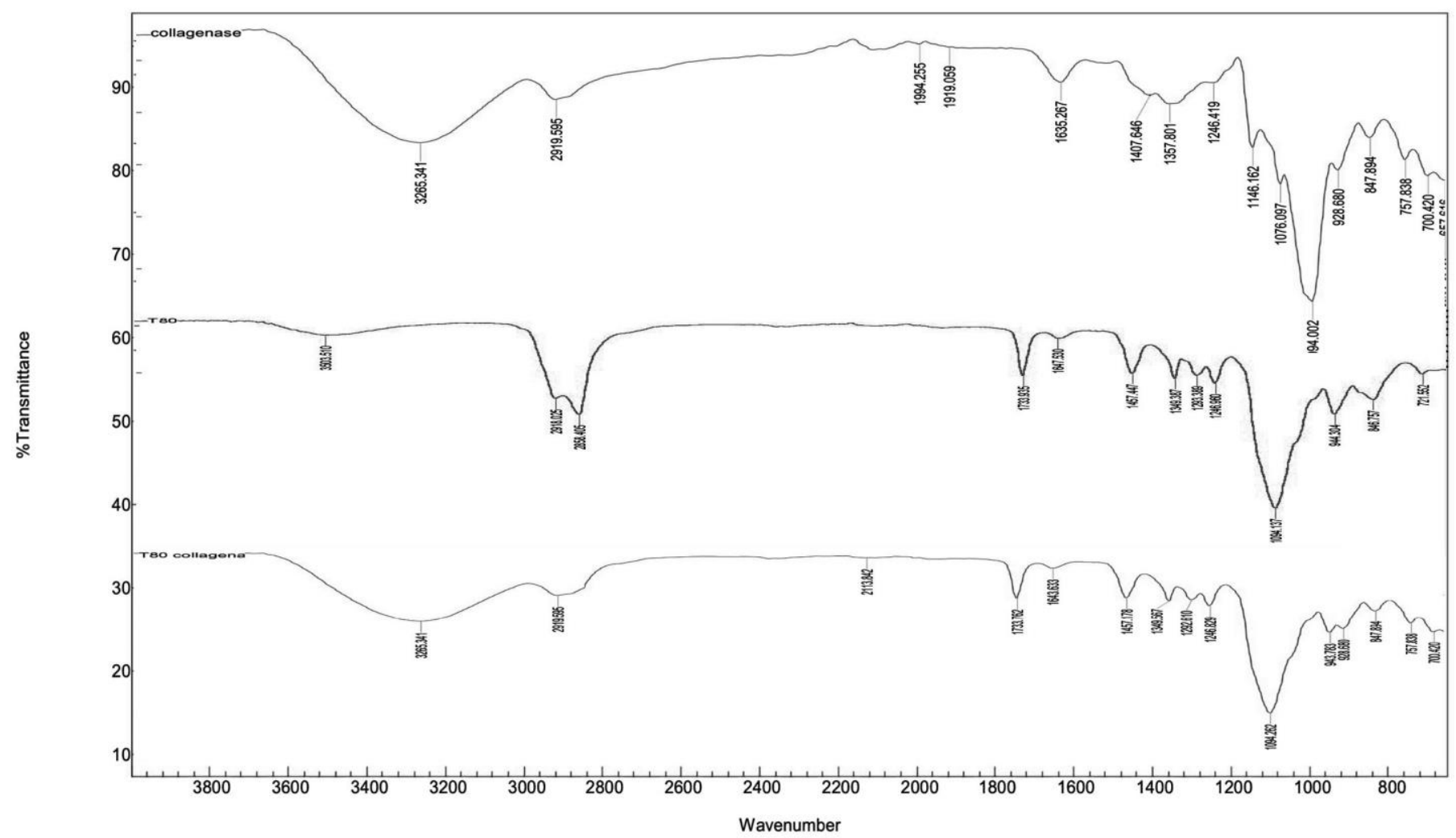

Figure 2(b). Infrared spectra of COLG, Tween 80 and COLG-Tween 80 mixture

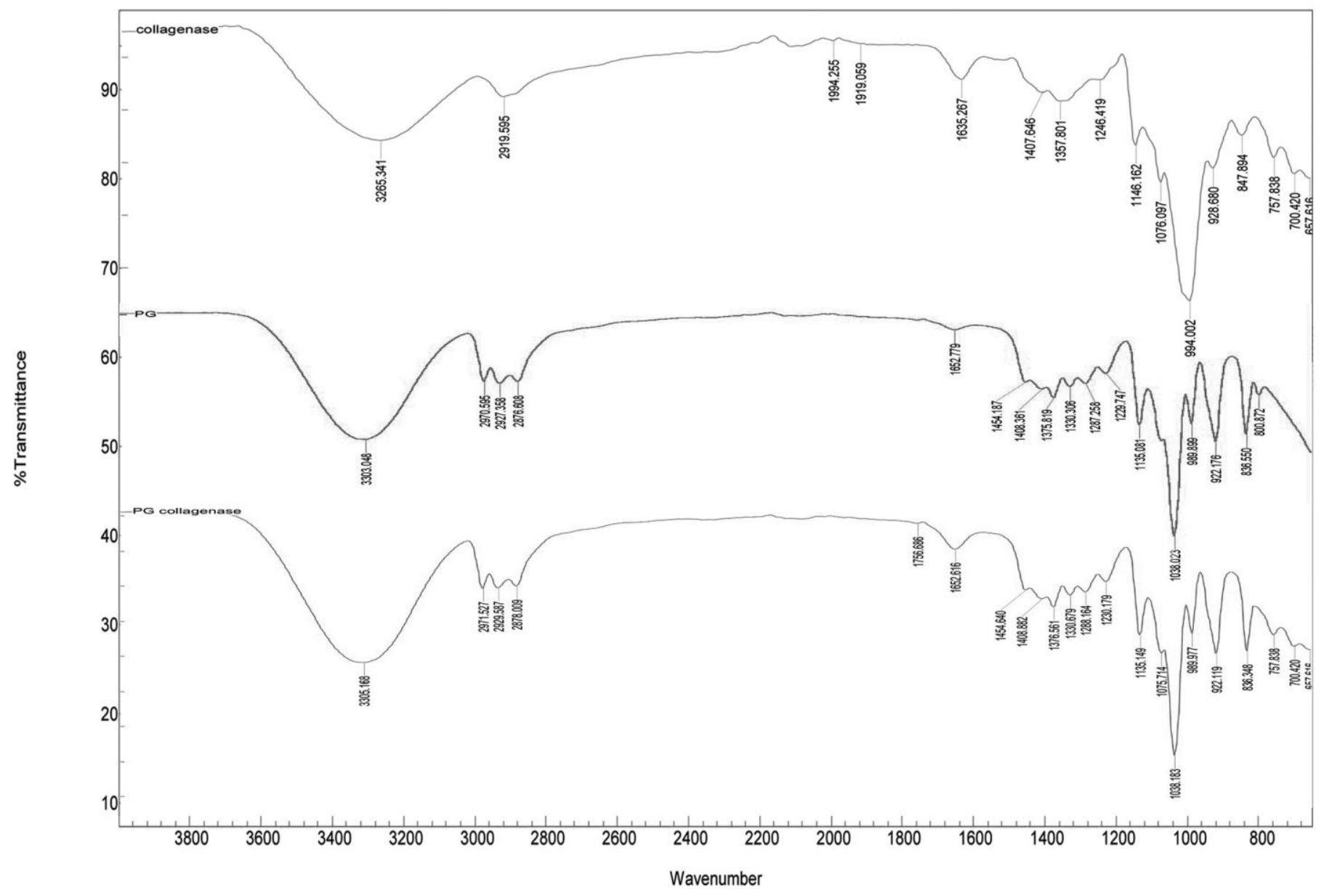

Figure 2(c). Infrared spectra of COLG, PG and COLG-PG mixture. 


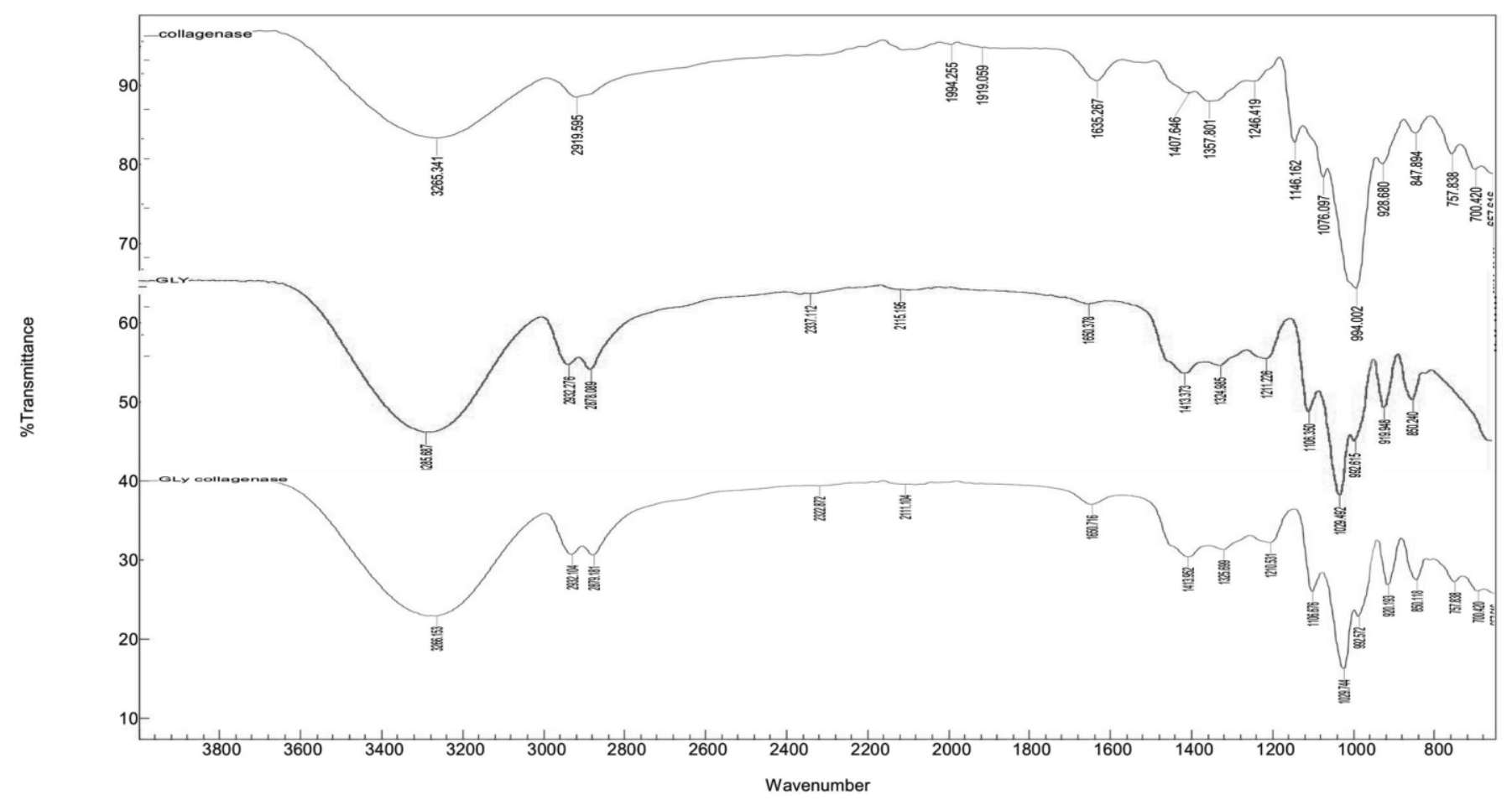

Figure 2(d). Infrared spectra of COLG, GLYC and COLG-GLYC mixture.

We observed that all characteristic peaks of enzyme COLG were retained without any significant changes in the binary mixtures with oleic acid (Figure. 2a), Tween 80 (Figure. 2b), PG (Figure. 2c) and GLYC (Figure. 2d). Thus it represents the compatibility of the enzyme with selected additives. The peak wave numbers of pure COLG and in the binary mixture are summarized in Table 4.

Table 4. IR spectroscopic analysis pure COLG and in binary mixture represent peak wave numbers of $\left(\mathrm{cm}^{-1}\right)$.

\begin{tabular}{|l|c|c|c|c|c|c|c|}
\cline { 2 - 8 } \multicolumn{1}{c|}{} & $\begin{array}{c}\text { Amide } \\
\text { A }\end{array}$ & $\begin{array}{c}\text { Amide } \\
\text { B }\end{array}$ & $\begin{array}{c}\text { Amide } \\
\text { I }\end{array}$ & $\begin{array}{c}\text { Amide } \\
\text { II }\end{array}$ & $\begin{array}{c}\text { Amide } \\
\text { III }\end{array}$ & $\begin{array}{c}\text { Amide } \\
\text { IV }\end{array}$ & $\begin{array}{c}\text { Amide } \\
\text { V }\end{array}$ \\
\hline Pure COLG & 3265 & 2919 & 1635 & 1407 & 1246 & 757 & 700 \\
\hline COLG:Oleic acid & 3301 & 2922 & 1634 & 1460 & 1240 & 757 & 700 \\
\hline COLG:Tween80 & 3246 & 2916 & 1643 & 1457 & 1246 & 753 & 702 \\
\hline COLG:PG & 3305 & 2929 & 1652 & 1454 & 1230 & 757 & 700 \\
\hline COLG:GLYC & 3266 & 2932 & 1650 & 1413 & 1210 & 755 & 703 \\
\hline
\end{tabular}

\section{Non-denaturing SDS-PAGE and Densitometry}

The interactive effect of COLG/additives on concentration of enzyme and its purity was studied on non-denatured SDS-PAGE gel [29]. Protein bands corresponding to control COLG were well resolved, sharp, symmetrical and with molecular weight at about $120 \mathrm{kDa}$ (Figure. 3a). The linearity of bands associated with varied concentration of control COLG $(2.5-40 \mu \mathrm{g} / 10 \mu \mathrm{l})$ was observed distinct. The pixel intensity of standard COLG solution $(10 \mathrm{mg} / \mathrm{ml})$ resulted by 'GelQuant' expressing the area (band volume) of peaks was calculated and linearity curve was plotted (Figure. 3b). Compatibility of COLG with different additives (Figure. 3c) was calculated using the pixel intensity of gel bands representing specific binary blends and comparing the same with the linear plot. Oleic acid, Tween 80, PG and GLYC found compatible with COLG in the form of the physical mixture since no appreciable variation in binary blends were detected in its protein concentration in comparison with control COLG (Table 5). The physical mixtures of COLG with the selected additives did not reveal any reduction in protein concentration. Moreover, no noticeable sign of protein fragments, aggregation or degradation caused due to interaction of these additives with enzyme was observed on the gel.

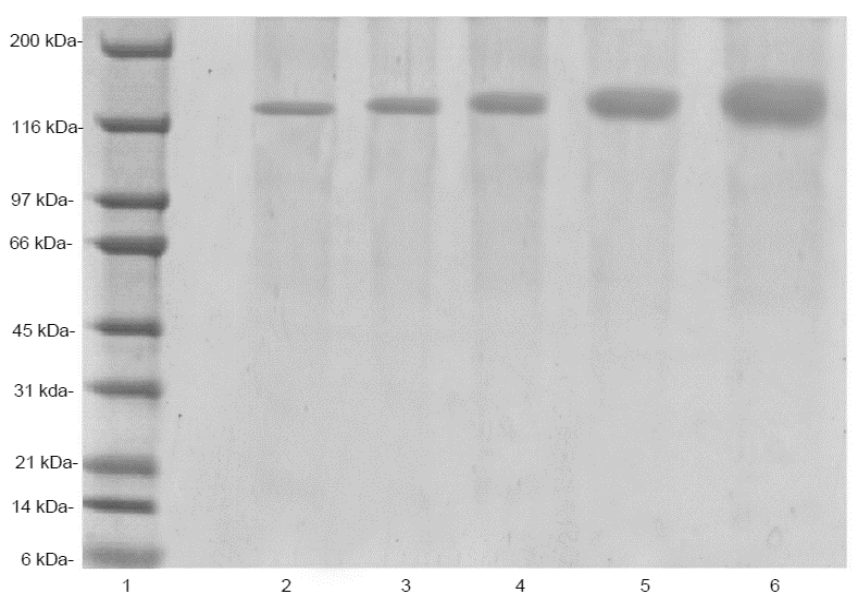

Figure 3(a). SDS-PAGE image with std. protein ladder (Lane 1) with different concentrations of standard collagenase (Lane 2-6).

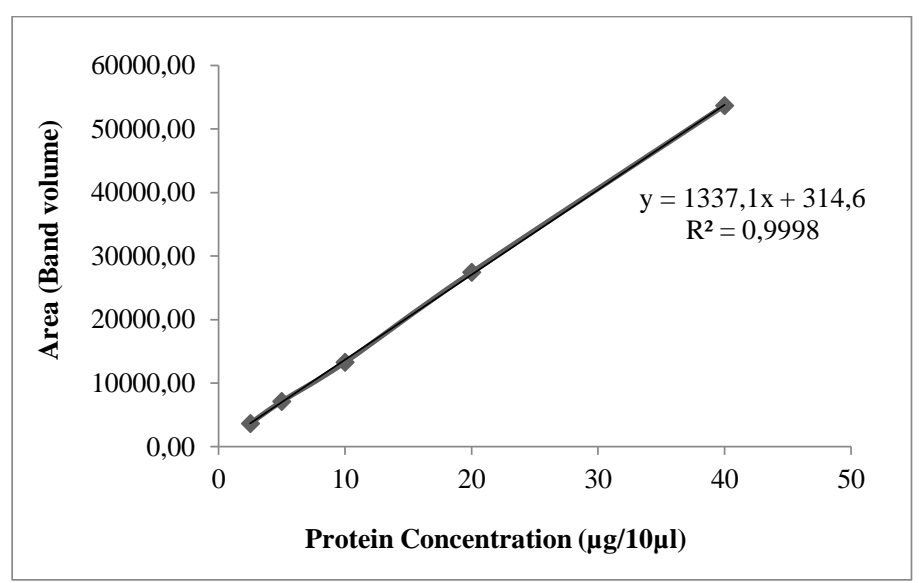

Figure 3(b). Calibration curve build up by plotting area (Band volume) of electrophoretic band relative to COLG standard solution at different concentration 


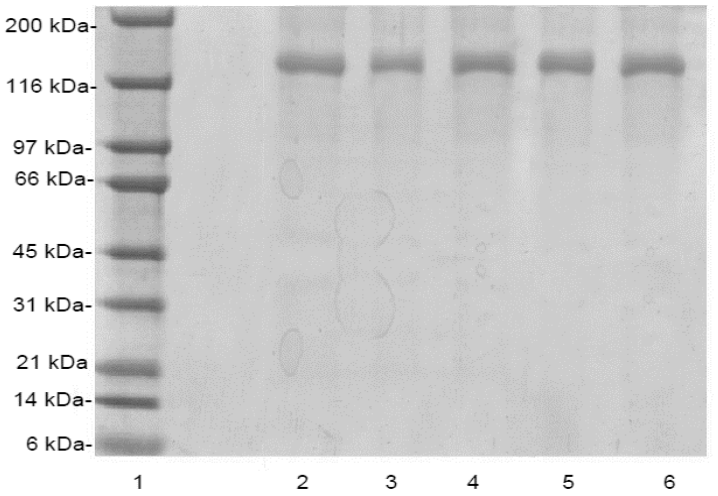

Figure 3(c). SDS-PAGE analysis of physical mixtures under non-reducing conditions (Lane 1: Std. protein ladder, Lane 2: control COLG $120 \mathrm{kDa}$, Lane 3: physical mixtures of oleic acid with COLG, Lane 4: physical mixtures of Tween 80 with COLG, Lane 5: physical mixtures of PG with COLG, Lane 6: physical mixtures of GLYC with COLG).

Table 5. Different physical mixtures loaded serially in the well of SDS-PAGE and their corresponding are (band volume).

\begin{tabular}{|c|c|c|c|}
\hline Lane & Physical Mixture & $\begin{array}{c}\text { Area } \\
\text { (Band volume) }\end{array}$ & $\begin{array}{c}\text { Protein } \\
\text { concentration } \\
(\boldsymbol{\mu g} / \mathbf{1 0} \boldsymbol{\mu l})\end{array}$ \\
\hline Lane 1 & Control sample & 27040.61 & 19.72 \\
\hline Lane 2 & COLG+ Oleic acid & 26404.93 & 19.26 \\
\hline Lane 3 & COLG+ Tween 80 & 26906.10 & 19.62 \\
\hline Lane 4 & COLG+ PG & 26395.35 & 19.25 \\
\hline Lane 5 & COLG + GLYC & 27152.82 & 19.80 \\
\hline
\end{tabular}

\section{Circular Dichroism (CD) Spectroscopy}

Dissociation of COLG in the combination with different additives was investigated by CD spectroscopy in the $190-300 \mathrm{~nm}$ range. COLG exhibit a minimum at about $210 \mathrm{~nm}$ while maximum at about $200 \mathrm{~nm}$ in the far UV region. The maximum at $200 \mathrm{~nm}$ in CD spectra of native COLG represents triple folded helix.

We observed that there were no significant alterations in confirmation of native folded COLG (Figure. 4). Minimum molar ellipticity at 205-225 nm comprises a broad $\alpha$-helical secondary structure. A negative maximum corresponds to the presence of the aromatic residues in the form of the anti-parallel $\beta$-helices. The band attenuation is blamed towards dissociation, while the strengthening is associated with enhancement of monomer units [30,31]. The molar ellipticity of native COLG at 200 and $210 \mathrm{~nm}$ was observed to be $-2.81 \times 10^{-6}$ and $-2.03 \times 10^{-6}$ deg. $\mathrm{cm}^{2} . \mathrm{mol}^{-1}$. No significant variation was seen in molar ellipticity of COLG in presence of different permeation enhancers. The overall conformational stability of COLG remained unchanged in these physical mixtures.

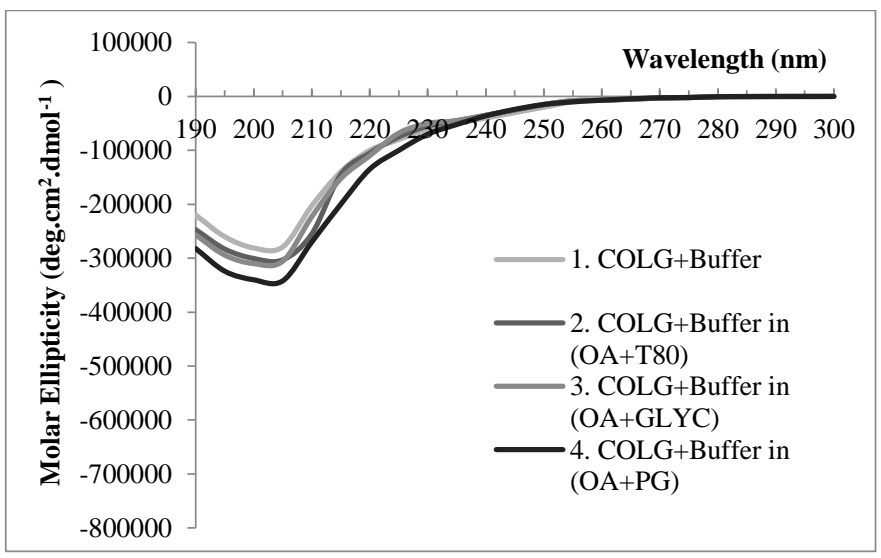

Figure 4. Far-UV CD spectra of native COLG in the presence of oleic acid, Tween 80, PG and GLYC.

\section{Content analysis by UV spectrophotometer for isothermal stress studies}

In the isothermal stress studies, the previously stored physical mixtures at two different temperatures-conditions viz. $25^{\circ} \mathrm{C} \pm 2^{\circ} \mathrm{C} / 60 \pm 5 \% \mathrm{RH}$ (accelerated) and $5^{\circ} \mathrm{C} \pm 3^{\circ} \mathrm{C}$ (control) for 4 weeks in humidity chambers was determined for the content of enzyme COLG by using UV Spectrophotometer.

It is essential that COLG should exhibit minimum 0.5 to 5 units of specific activity per mg of protein calculated with reference to L-leucine standard curve provided the enzyme mixture is dissolved in inert carrier solvent with $60 \%$ aqueous solution before treating the viable tissue [32]. The commercial COLG isolated from $\mathrm{Cl}$. histolyticum exhibit $125-500$ Units $/ \mathrm{mg}$ specific activity according to manufacturer's specifications. The specific activity and purity of COLG enzyme in the binary blend was calculated based on standard COLG enzyme activity which was observed $298.88 \pm 1.36$ Units $/ \mathrm{mg}$ in the crude state [6] and $303.03 \pm 1.16$ Units/mg after purification and lyophilization. Table 6 indicates concentration and \% purity of standard COLG in physical mixtures in control and stress conditions. The values were found within the acceptable range which reveals the stable nature of the COLG with oleic acid, Tween 80, PG and GLYC.

Table 6. Evaluation of stabilised binary blends after 4 weeks of storage at $25^{\circ} \mathrm{C}$ $\pm 2^{\circ} \mathrm{C} / 60 \pm 5 \%$ RH (IST) and at $5^{\circ} \mathrm{C} \pm 3^{\circ} \mathrm{C}$ (control).

\begin{tabular}{|c|c|c|c|c|}
\hline \multirow{2}{*}{ Components } & \multicolumn{2}{|c|}{ Control } & \multicolumn{2}{c|}{ Induced Stress } \\
\cline { 2 - 5 } & $\begin{array}{c}\text { concentration } \\
\text { Units/mg }\end{array}$ & $\begin{array}{c}\text { purity } \\
\%\end{array}$ & $\begin{array}{c}\text { concentration } \\
\text { Units/mg }\end{array}$ & $\begin{array}{c}\text { purity } \\
\%\end{array}$ \\
\hline COLG & $297.26 \pm 1.16$ & 98.10 & $272.56 \pm 2.33$ & 89.95 \\
\hline COLG + Oleic acid & $276.68 \pm 2.02$ & 91.30 & $260.21 \pm 1.16$ & 85.87 \\
\hline COLG + Tween 80 & $277.50 \pm 2.33$ & 91.58 & $265.98 \pm 1.16$ & 87.77 \\
\hline COLG + PG & $282.44 \pm 2.33$ & 93.21 & $266.80 \pm 2.02$ & 88.04 \\
\hline COLG + GLYC & $281.62 \pm 2.02$ & 92.93 & $265.15 \pm 1.16$ & 87.50 \\
\hline
\end{tabular}

CONCLUSIONS

In view of delivering therapeutic enzyme - COLG through colloidal systems, various additives were studied. This is the first ever pre-formulation study of our knowledge, focussed on enzyme as a therapeutic macromolecule governing its efficacy to incorporate into colloidal delivery. Initially, the suitability of different solvents system in solubilisation of enzyme was investigated which was followed by determination of efficiency of specific surfactants and cosurfactants to emulsify different oils. The compatibility of COLG along with selected additives was inspected by FTIR-ATR spectroscopy since it favours analysis of liquid and semisolid samples as well. The results of FTIR was further confirmed by nondenaturing SDS PAGE with densitometry which is a routinely used technique in proteomics to detect aggregation and denaturation of protein, peptides and enzymes on polyacrylamide gel. Prediction of secondary structures of the enzyme with preserving its native $\alpha$-helical and $\beta$-sheet folding is very crucial for its retained and prolonged specific proteolytic activity which was examined by circular dichroism (CD) spectra. Surfactants are frequently blamed for the unfolding of the protein resulting loss of protein specificity and activity. Interestingly, the physical mixture of Tween 80 with COLG did not reveal any significant interaction probably due to its non-ionic nature. Among the various possible additives employed, oleic acid, Tween 80, PG and GLYC indicated their impartial behaviour and inert nature in diminishing physicochemical instability of COLG. These additives hence could be considered as excipients in delivering collagenase via colloidal dispersion.

\section{ACKNOWLEDGMENTS}

The authors are herewith gratefully acknowledge the financial support by University Grants Commission, New Delhi for UGC-BSR Fellowship (grant number: F-25/1/2014-15(BSR)/7-269/2009(BSR) $7^{\text {th }}$ Oct 2015) during research tenure. Authors also express their deep gratitude towards Dr. S. Sethupathy, Professor and Head, Dept. of Medical Biochemistry, Annamalai University for providing necessary lab facilities. 


\section{REFERENCES}

1. W. Wang, Advanced protein formulations, Protein sci. 24, 7, (2015).

2. L. Anil, K. Kannan, J. Pharm. Sci. Res. 10, 11, (2018)

3. N. Nezafat, M. Negahdaripour, A. Gholami, Y. Ghasemi, Trends Pharm. Sci. 1, 4, (2015).

4. M. H. E. Nagar, M. Mahdy, M. Selem, G. E. Maghraby, J. App. Pharm. Sci. 6, 3, (2016).

5. H. Y. Karasulu, B. Karabulut, G. Kantarci, I. Ozgüney, C. Sezgin, U. A. Sanli, E. Göker, Drug Deliv. 11, 6, (2004).

6. K. Krishnamoorthy, A. V. Landge, Braz. Arch. Biol. Technol. 61, (2018).

7. A. Shalviri, A.C. Sharma, D. Patel, A. Sayani, J. Pharm. Pharm. Sci. 14, 3 (2011).

8. P. Bummer, in Protein formulation and delivery. E. McNally, J. Hastedt eds, CRC press, Florida, 2008; pp.7-45.

9. A. A. Date, M. Nagarsenker, Int. J. Pharm. 329, 1, (2007).

10. A. Barth, Biochim. Biophys. Acta. 1767, 9, (2007)

11. G. M. Kirsten, L. M. Blancas-Mejia, B. Weber, J. Buchnar, Amyloid. 24, 1, (2007).

12. N. R. Pani, L. Nath, S. Acharya, Acta Pharm. 61, 2 (2011)

13. K. Pramod, C. V. Suneesh, S. Shanavas, J. Anal. Sci. Tech. 6, 34, (2015)

14. A. M. Cernada, J. C. Fernandez, L. P. Fernandez, L. R. Calvo, D. Rojas, G. Figueredo, A. Rodríguez, C. Fernández, T. Sosa, G. Amaro, Bioprocess Int. 15, 2, (2016).

15. US-FDA: Stability testing of new enzyme substances and products International conference on harmonisation of technical requirements for registration of pharmaceuticals for human use. Q1A (R2), current step 4 version, (2003).
16. H. Anushree, and K. Ajay, Transdermal Delivery of Peptides and Proteins in Peptide and protein delivery, W. Chrisvander eds. Elsevier, London, 2011; pp. 69-83.

17. J. Angelo, S. Hempstead, H. Edwin, United States patent no. 3705083 (1972)

18. M. Zdravka, S. Dubravka, S. Georg, K. Martin, J. Addit. Food Chem. 5, 2 (2014).

19. U. Laemmli, Nature. 227, 5259, (1970).

20. D. R. Perinelli, M. Cespi, S. Pucciarelli, S. Vincenzetti, L. Casettari, J. Lam, S. Logrippo, E. Canala, M. Soliman, Curr. Pharm. Biotechnol. 18, 5, (2017)

21. S. T. L. Philominathan, O. Matsushita, R. Gensure, J. Sakon, FEBS J. 276 13, (2009).

22. N. Patil, P. Devarajan, Drug Deliv. Transl. Res. 4, 5, (2014).

23. H. Hossam, Indian J. Biotechnol. 7, 3, (2008).

24. S. M. Daboor, S. M. Budge, A. E. Ghaly, S. L. Brooks, D. Deepika, Am. J. Biochem. Biotechnol. 6, 4, (2010).

25. Y. S. Elnaggar, M. A. El-Massik, O. Y. Abdallah, Int. J. Pharm. 380, 1, (2009).

26. L. Wang, J. Dong, J. Chen, J. Eastoe, X. Li, J Colloid and Interface Sci. 330 , 2, (2008)

27. D. A. Farghaly, A. A. Aboelwafa, M. Y. Hamza, M. I. Mohamed, J. Liposome Res. 28, 2, (2017).

28. J. Yang, G. Sule-Suso, D. Sockalingum, Proc. SPIE. 6859, (2008).

29. M. Magdy, A. Muharram, Saudi Pharm. J. 25, 3, (2017).

30. N. J. Greenfield, Nat. Protoc. 1, 6, (2006).

31. A. Micsonai, F. Wien, L. Kernya, Y. Lee, Y. Goto, M. Réfrégiers, J. Kardos, Proc. Natl. Acad. Sci. 112, 24, (2015).

32. W. Galbraith, European patent no. EP0039726A1 (1981). 